\title{
TENGELYEK CSAPÁGYAZÁSÁNAK OPTIMÁLÁSA TÖMEG- ÉS KÖLTSÉGMINIMUMRA
}

\author{
Sztankó Bálint \\ hallgató, Miskolci Egyetem, Gép- és Terméktervezési Intézet \\ 3515 Miskolc, Miskolc-Egyetemváros, e-mail: sztanko.balint1995@gmail.com \\ Szabó J. Ferenc \\ egyetemi docens, Miskolci Egyetem, Gép-és Terméktervezési Intézet \\ 3515 Miskolc, Miskolc-Egyetemváros, e-mail: machszf@uni-miskolc.hu
}

\begin{abstract}
Absztrakt
Optimumkeresö módszerek ismeretében felépítjük az optimálás folyamatát egysoros mélyhornyú golyóscsapágyakkal csapágyazott tengely esetére. Az optimumkeresés célja a minél kisebb csapágytömeg és a csapágy költségek alacsonyan tartása. Ezek mellett megvizsgáljuk a tengely hosszméreteinek hatását az optimális értékekre.
\end{abstract}

Kulcsszavak: optimálás, egysoros mélyhornyú golyóscsapágy, tömegminimum, tengely, csapágy, költség

\begin{abstract}
After the overview of several optimization algorithms, in this paper the optimization system and process is built for shafts supported by deep grove ball bearings. The objective function of the optimization can be the total mass or the total costs of the bearings. The effects of the shaft length dimensions are also taken into consideration.
\end{abstract}

Keywords: optimization, deep grove ball bearings, minimum of mass, shaft, bearing, costs

\section{Bevezetés}

Az optimumkeresés napjainkra egy mindennapos feladattá vált, folyamatosan döntéseket kell hoznunk az élet minden területén. Egyes tudomány területeken, mint például a gépészet, az optimumkeresésnek és az optimális megoldások használatának kiemelt szerepe van, ahogy a legtöbb müszaki területen is. Ahhoz, hogy egy termék minden elvárásnak megfeleljen különbözö szempontok szerint meg kell vizsgálni. A szempontok melyek szerint vizsgáljuk a terméket és annak megoldásait egy optimálásban implicit és explicit feltételként is felhasználhatók lesznek.

A célunk, hogy az optimum kereső eljárások segítségével felépítsünk egy olyan megoldás menetet, melynek segítségével kiszámítható a szükséges csapágyak tömege és megbecsüljük a várható csapágyköltséget. Az eredmények eléréséhez fel kell használni a tengelycsapágyazás mechanikai hátterét és a csapágyélettartam számításának elméleti hátterét. 


\section{CAD és végeselemes endszerek fejlődése, az optimumkeresés különböző ágai}

\subsection{CAD és végeselemes rendszerek fejlödésének föbb mérföldkövei [3]}

A napjainkban használt végeselemes és CAD rendszerek megjelenése és fejlődése a II. világháború után kezdődött. Ekkorra a számítás technika elérte azt a fejlettségi szintet, amellyel könnyen és gyorsan lehetett a mérnöki problémákat megoldani.

- Az első grafikus CAD rendszert az USA légierője alkalmazta, ez volt a SAGE.

- 1960-ban jelent meg a SKETCHPAD és a DAC.

- $\quad$ 1973-ban amerikai autógyártók elkezdték a CADAM rendszer fejlesztését.

- $\quad$ 1977-ben Marcel Dassault háromdimenziós tervezőprogramot kezdett fejleszteni ez lett a CATIA. Árusítása 1982-ben kezdődött.

- 1980-ban a T\&W Systems létrehozta a VersaCAD programot. 1982-ben megalakul az Autodesk cég John Walker vezetésével. 1982-ben kiadták az AutoCAD első verzióját, amely Mike Riddle MicroCAD programján alapult.

- Az 1970-es évek végére a felhasználók igényelték a CAD fájlok egységesítését. 1980-ban megjelent az IGES, amely ipari szabvánnyá vált. 1983-ban fejlesztések kezdődtek, melynek eredménye a STEP formátum lett. 1991-ben megjelent az első STEP fordító program.

- Az 1980-as években a személyi számítógépek elterjedése nagy lökést adott a CAD és végeselemes rendszerek fejlesztöinek.

- $\quad$ 1995-ben a gyártók bevezették a Windows rendszerrel kompatibilis szoftverjeiket.

- A CAD rendszer gyártók elkezdtek programjaikba végeselemes programokat integrálni. Megjelentek az AUTOCAD, ProEngineer és a SolidEdge szoftverekbe integrált COSMOS és COSMOS/M programok.

- Napjaink legmeghatározóbb végeselemes rendszerei képesek CAD rendszerekhez integrálódni. Ezek közül fontos megemlíteni az ANSYS, a NASTRAN, a MARC és az ABAQUS szoftvereket.

\subsection{Az optimálás különböző ágai}

- Topológia optimálás:

Topológia optimálás alatt az alkatrész vagy gépelem szerkezetének optimálását értjük. Meg lehet határozni azt, hogy az alkatrész vagy gépelem mely része nem befolyásolja nagy mértékben a strukturális viselkedést, ezen részek az optimálás után törölhetők. Ezért az optimálás ezen ága jól alkalmazható tartók (tartó rudak, rácsos tartók) méretezésére. Tartószerkezetek és rácsos tartók méretezésénél ez az eljárás le tudja csökkenti a felhasznált rudak számát. [8]

- Alakoptimálás:

Elsősorban már megtervezett gépelemek optimálására használatos eljárás. A tervezéskor használt változók és a tervezett paraméterek figyelembevétele mellett, egy célfüggvény segítségével meg lehet határozni az optimális alkatrész geometriát, így csökkenteni lehet a belső feszültségeket és növelni az élettartamot. [8]

- Multidiszciplináris optimálás

A komplex feladatoknál egyre pontosabb eredményeket kell szolgáltatnia a vizsgálatot végző programoknak. Ezen vizsgálatoknál egyszerre több hatás is ér egy alkatrészt (például mechanikai terhelés és hőterhelés együttes jelenléte). A különböző terhelések egymás utáni figyelembevétele nem mindig vezet jó eredményhez, figyelembe kell venni a különböző terhelések egymásra való hatását. [8]: 
- Többcélfüggvényes optimálás:

Az első többcélfüggvényes optimálást (vektoroptimálás) Pareto (1896) publikálta. Az 1960-as évekig viszonylag keveset foglalkoztak vele, a témával kapcsolatban több cikk is megjelent. Ezek a cikkek fóként az optimálás elméletével és döntéshozatali alkalmazásával foglalkoztak, mérnöki alkalmazásról kevés publikáció készült.

Többcélfüggvényes optimálásról akkor lehet beszélni, ha egynél több függvénnyel történik az optimumkeresés (például kéttámaszú tartó esetén az egyik célfüggvény a minimális költség, a másik a maximális merevség). Ebben az esetben az egyes célfüggvényeknek külön kell minimum és maximum értéket meghatározni, ez kompromisszumot jelent a függvények közt. Pareto optimum definíciója szerint akkor van optimum, ha egyik célfüggvény értéke sem javítható úgy, hogy legalább egy másik célfüggvény értéke ne romlana. [10]

\subsection{Végeselemes rendszerek fejlődésének története}

A végeselemes módszereknek és az optimumkeresésnek gátat szabott a számításigényes matematikai háttér, melyet csak a XX. század technológiai fejlődése tudott csak feloldani. A II. világháború hatására elindult fejlesztések meghozták a számítástechnika fejlődését. Ez a fejlődés magával hozta a már említett két tudományág fejlődését.

Az 1950-es években a számítástechnika használata lehetővé vált a müszaki tudományok különböző területein. Ezek a gépek sok helyet foglaltak, üzemeltetésük képzett személyzetet igényelt. Az 1960-as évek első felében megjelentek a többváltozós algoritmusok, nemlineáris függvények korlátozásos és korlátozás nélküli optimumainak számítására alkalmas gépek.

A legnagyobb eredményeket az 1973-as amerikai olajválság hatására létrejött helyzet okozta. A repülés ekkor nagy fejlődésen és elterjedésen ment keresztül, de az olajválság okozta problémák új fejlesztési területekre helyezték a hangsúlyt. Optimalizálni tudták az üzemanyag felhasználást új alumínium ötvözetek kifejlesztésével és optimált felhasználásukkal. Az ekkor elért eredmények nagy népszerüséget hoztak az optimalizálásnak és külön tudománnyá nőtte ki magát. A repülőgép ipar után az építőiparban kezdték el használni, majd elterjedt a gépészetben is. Ma már egy termék fejlesztése elkerülhetetlen optimum kereső eljárások nélkül.

\section{Egysoros mélyhornyú golyóscsapágyak optimálása}

Az optimáláshoz szükséges csapágyadatokból grafikonok rajzolhatók, melyek alapján közelítő egyenletek írhatók fel. A kapott egyenletekből, a csapágyazás egyenleteiből és a mechanikában használt összefüggések segítségével egy az optimáláshoz alkalmas számolótábla hozható létre.

Az optimálást jelen esetben egysoros mélyhornyú golyóscsapágyakkal végezzük, az SKF 61000-es sorozatú csapágyak adatainak felhasználásával [1]. Az eredmények pontossága érdekében a lehető legnagyobb méret tartományt vizsgáljuk, jelen esetben $10 \mathrm{~mm}$-től $280 \mathrm{~mm}$-ig (csapágy belső átméröje). Az optimálás a dinamikus alapterhelés - tömeg függvény segítségével történik.

\subsection{Dinamikus alapterhelés - tömeg függvény}

Az adatokból kapott görbére egyenletek írhatók fel, melyekkel a lehető legpontosabban próbáljuk követni a kapott görbét. A közelítést lineáris, exponenciális, hatvány és többed fokú polinomok egyenleteinek a segítségével végezzük. A továbbiakban a legpontosabb közelítést adó egyenlettel folytatjuk az optimálást. 


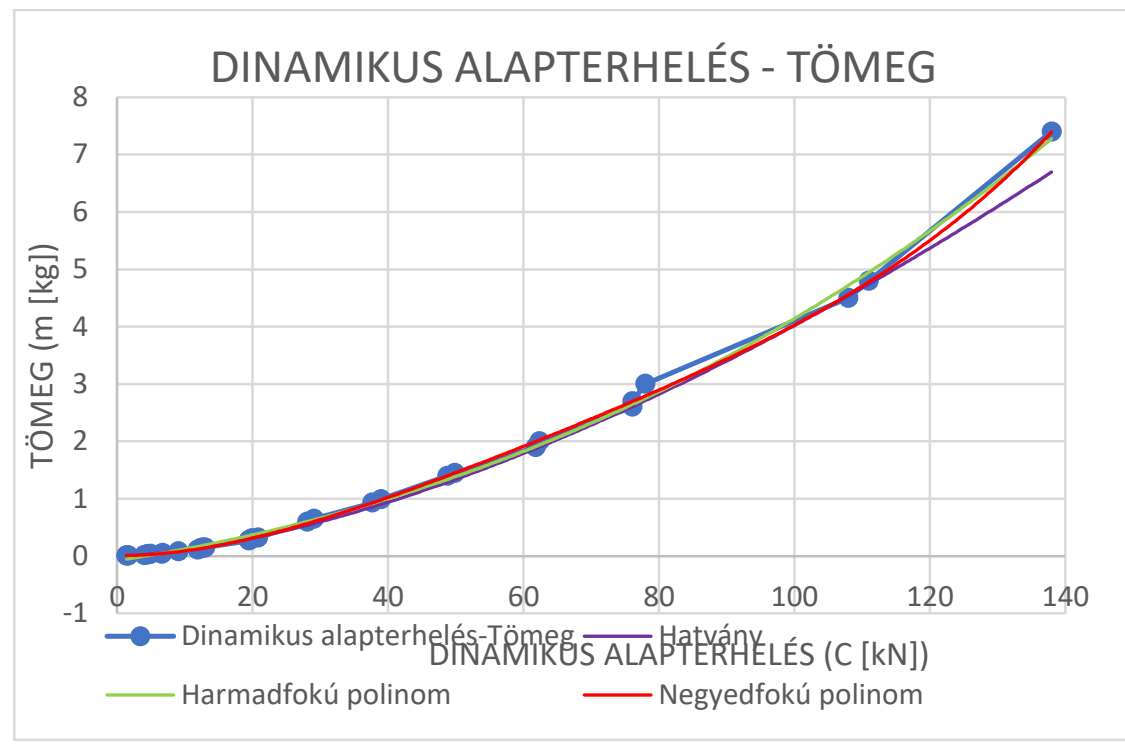

1. ábra. Dinamikus alapterhelés - tömeg függvény

A dinamikus alapterhelés és tömeg függvény hatvány egyenlettel, harmad és negyedfokú polinom egyenletével írható le a legjobban.

A közelítés során a hatvány egyenlettel való közelítés hozta első ránézésre a legjobb eredményt, ez látszik az ellenőrzés (1. táblázat) adataiban is. Második legjobbnak a harmadfokú polinom bizonyult, mert kis terhelések esetén negatív eredmények jönnek ki az ellenőrzés során, nagy általánosságban elég pontos eredményt kapunk ezzel az egyenlettel. A harmadik legjobb eredményt a negyedfokú polinom adta.

A három egyenlet sorrendje, ha csak a korrelációs együtthatóra hagyatkoznánk: harmadfokú polinom $(0,99886)$, hatvány $(0,99844)$ és negyedfokú polinom $(0,99808)$ egyenlet.

A három görbét leíró függvény egyenletei:

harmadfokú polinom:

$$
y=4 \cdot 10^{-7} \cdot x^{3}+0,0002 \cdot x^{2}+0,0185 \cdot x-0,0821
$$

hatvány:

$$
y=0,0027 \cdot x^{1,5854}
$$

negyedfokú polinom:

$$
y=4 \cdot 10^{-8} \cdot x^{4}-9 \cdot 10^{-6} \cdot x^{3}+0,0009 \cdot x^{2}-0,0004 \cdot x+0,0078
$$

Tehát az 1. ábra, az ellenőrzés és a korrelációs együttható alapján kijelenthető, hogy az SKF 61000-es csapágyszéria esetén harmadfokú polinommal történő számolás a célravezető. 
1. táblázat. Részlet az ellenörzéskor kapott eredményekböl

\begin{tabular}{|c|c|c|c|c|}
\hline C $[\mathrm{kN}]$ táblázatból & $\begin{array}{c}\text { Tömeg }[\mathrm{kg}] \\
\text { táblázatból }\end{array}$ & $\begin{array}{c}\text { Tömeg }[\mathrm{kg}] \\
\text { harmadfokú } \\
\text { polinommal } \\
\text { számolva }\end{array}$ & $\begin{array}{c}\text { Tömeg }[\mathrm{kg}] \\
\text { hatvány } \\
\text { közelítéssel } \\
\text { számolva }\end{array}$ & $\begin{array}{c}\text { Tömeg }[\mathrm{kg}] \\
\text { negyedfokú } \\
\text { polinommal } \\
\text { számolva }\end{array}$ \\
\hline 1,380 & 0,006 & $-0,056$ & 0,004 & 0,009 \\
\hline 1,430 & 0,006 & $-0,055$ & 0,005 & 0,009 \\
\hline 1,560 & 0,007 & $-0,053$ & 0,005 & 0,009 \\
\hline 1,680 & 0,008 & $-0,050$ & 0,006 & 0,010 \\
\hline 4,030 & 0,018 & $-0,004$ & 0,025 & 0,020 \\
\hline 4,360 & 0,022 & 0,002 & 0,028 & 0,022 \\
\hline 28,100 & 0,600 & 0,605 & 0,535 & 0,532 \\
\hline 29,100 & 0,650 & 0,635 & 0,565 & 0,565 \\
\hline 37,700 & 0,930 & 0,921 & 0,852 & 0,870 \\
\hline 39,000 & 0,990 & 0,967 & 0,899 & 0,920 \\
\hline 48,800 & 1,400 & 1,343 & 1,283 & 1,312 \\
\hline 49,900 & 1,450 & 1,389 & 1,329 & 1,359 \\
\hline \multicolumn{2}{|r|}{ Átlagos eltérés } & $0,627 \%$ & $4,646 \%$ & $1,447 \%$ \\
\hline
\end{tabular}

\subsection{Optimálás menetének bemutatása példán keresztül}

Az optimálás következö lépéseként egy csapágyazott tengelyre erőket helyezünk, majd a 2. ábra alapján fel tudjuk írni a nyomatéki egyenleteket, valamint a keresett terhelések egyenleteit. [4] [7]

A számításhoz használjunk példaként egy elötéttengelyt, melyet egy villanymotor szíjhajtással hajt meg, majd a tengelyről a hajtást egy lánchajtással visszük tovább.

1. lépés: explicit és implicit feltételek meghatározása

Explicit feltételként megadható a két csapágy távolsága és a csapágy és a terhelés közötti távolság tartománya.

Például: $0 \leq a \leq 500[\mathrm{~mm}]$

$$
0 \leq b \leq 500[\mathrm{~mm}]
$$

Implicit ételek megadása nem kötelező, a feladat kibővítéseként például meg lehet adni a tengelyre vonatkozó kritériumokat.

2. lépés: bemenő és rögzített bemenő adatok felvétele, például: csavaró nyomaték, szíj- és lánchajtásból származó nyomatékok

3. lépés: $F_{A}$ és $F_{B}$ csapágyat terhelő erők felvétele

4. lépés: csapágyazáshoz használatos $P_{A}=F_{A}$ és $P_{B}=F_{B}$ érté meghatározása

5. lépés: csapágyak dinamikus alapterhelésének kiszámítása

$$
C=P \cdot \sqrt[3]{L_{10 h} \cdot \frac{60 \cdot n}{10^{6}}}
$$




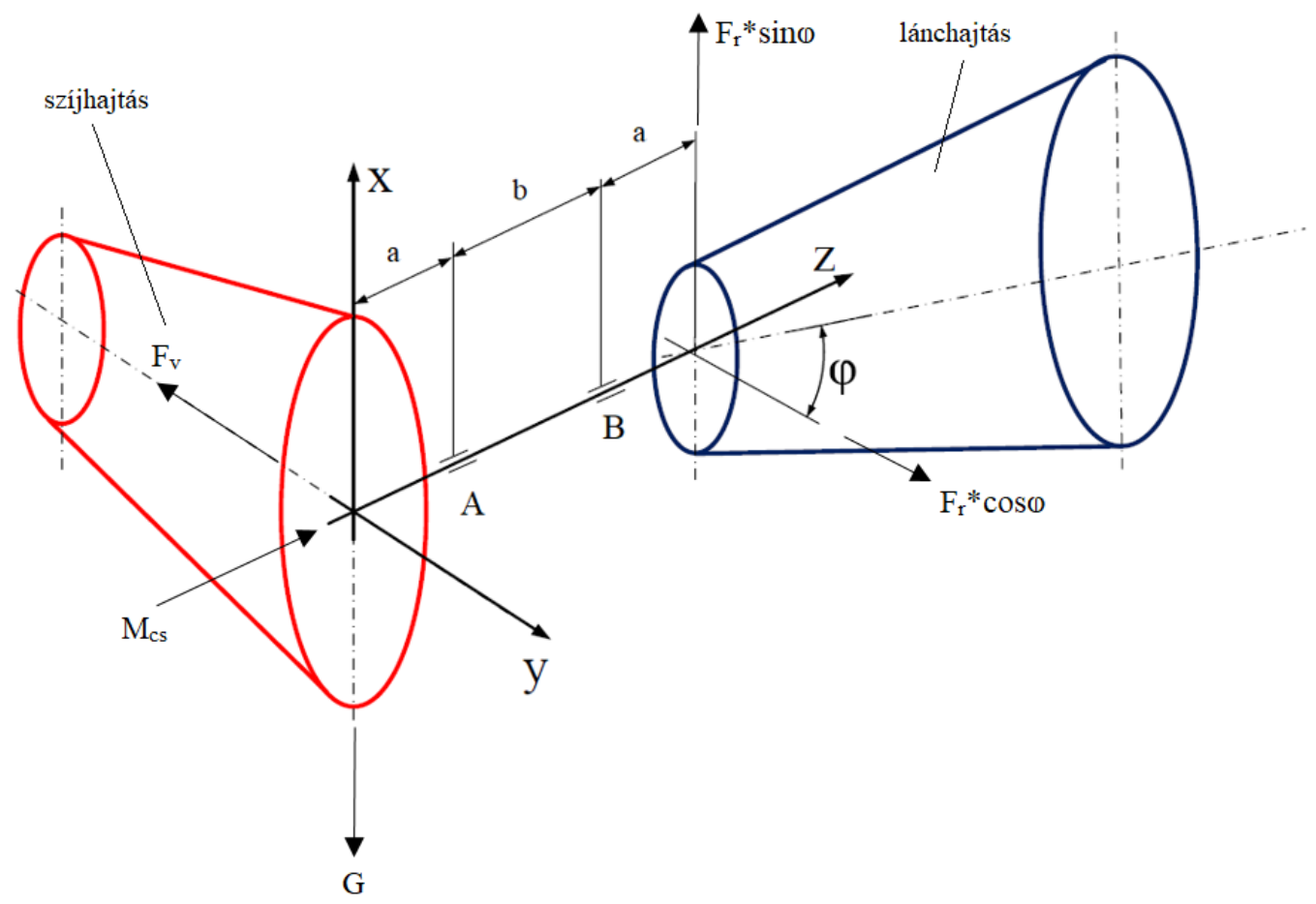

2. ábra. Optimálási példa elrendezése [4]

6. lépés: csapágytömegek és csapágy össztömeg kiszámítása

$$
\begin{gathered}
m=4 \cdot 10^{-7} \cdot x^{3}+0,0002 \cdot x^{2}+0,0185 \cdot x-0,0821 \\
f=m_{A}+m_{B}
\end{gathered}
$$

A fentiekben leírtakat más csapágyszériák esetén is lehet alkalmazni, csak arra kell figyelni, hogy minden csapágyszériának a saját dinamikus alapterhelés - tömeg függvényét legjobban leíró egyenletet használjuk.

\subsection{Számítási eredmények összehasonlítása}

A számítások megismétlése esetén ugyanazok a támasztó erők és csapágyterhelések jönnek ki eredményül. Egyedül a csapágyak tömege fog változni, mert a dinamikus alapterhelés-tömeg összefüggésénél felírt egyenlet mindegyik csapágy típusnál más. A felírt dinamikus alapterheléstömeg összefüggések alapján a 61000-es csapágyak harmadfokú polinommal, a 6000-es csapágyak harmadfokú polinommal, a 6200-as csapágyak negyedfokú polinommal, a 6300-as csapágyak harmadfokú polinommal és a 6400 -as csapágyak is harmadfokú polinommal való közelítés esetén szolgáltatják a legpontosabb eredményt. [1] [4] [7]

A katalógus adatok a kiszámított dinamikus alapterhelések alapján lettek SKF csapágykatalógusból [1] kikeresve. 
2. táblázat. Számított és katalógus adatok összehasonlitása

\begin{tabular}{|c|c|c|c|c|c|}
\hline \multirow{2}{*}{$\begin{array}{c}\text { Számított tömeg } \\
\text { adatok }\end{array}$} & \multicolumn{5}{|c|}{ Csapágy típusok } \\
\cline { 2 - 6 } & SKF 61000 & SKF 6000 & SKF 6200 & SKF 6300 & SKF 6400 \\
\hline$m_{A}[\mathrm{~kg}]$ & 0,406 & 0,309 & 0,175 & 0,269 & 0,173 \\
\hline$m_{B}[\mathrm{~kg}]$ & 0,774 & 0,559 & 0,472 & 0,544 & 0,491 \\
\hline$f=m_{A}+m_{B}[\mathrm{~kg}]$ & 1,18 & 0,868 & 0,647 & 0,813 & 0,664 \\
\hline $\begin{array}{c}\text { Katalógus tömeg } \\
\text { adatok }\end{array}$ & 0,600 & 0,260 & 0,290 & 0,230 & 0,270 \\
\hline$m_{A}[\mathrm{~kg}]$ & 0,930 & 0,600 & 0,460 & 0,630 & 0,530 \\
\hline$m_{B}[\mathrm{~kg}]$ & 1,530 & 0,860 & 0,750 & 0,860 & 0,800 \\
\hline$f=m_{A}+m_{B}[\mathrm{~kg}]$ & $77,12 \%$ & $99,08 \%$ & $86,27 \%$ & $94,53 \%$ & $83 \%$ \\
\hline pontosság
\end{tabular}

A táblázat eredményeiből jól látható, hogy az adott példa esetében az SKF 6000-es csapágyszériája estén lett a legpontosabb a számítás. Jelen esetben az SKF 6010-es és az SKF 6014-es csapágy tömege lett nagy pontossággal meghatározva, viszont a legkedvezőbb tömegértéket az SKF 6200-as csapágyszériája esetén kapjuk.

\subsection{Tengelyméret befolyásoló hatása az optimumkeresésben}

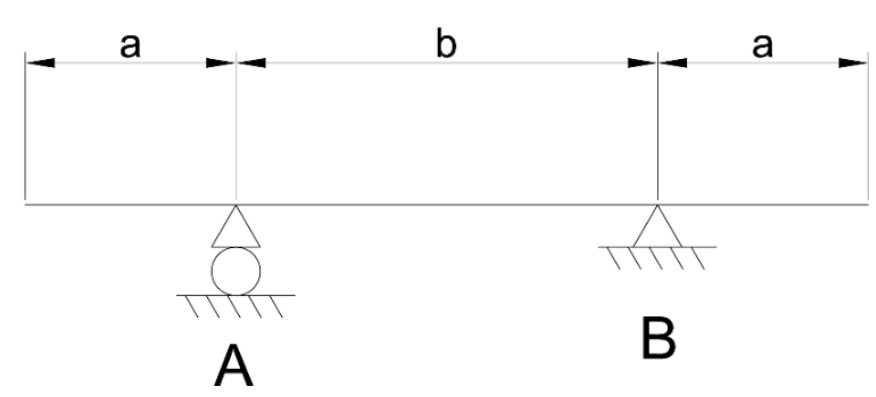

\section{3. ábra. A tengely és a csapágyazás vázlata}

Több csapágyszéria esetén történő számítást is figyelembe véve látható, hogy a 3.2. fejezetben található „a” és „b” értékének változtatásával befolyásolható a csapágyazás össztömege. Az „a” értékének csökkentésével csökkenteni lehet a csapágyak tömegét, míg „b” értékének növelése esetén mondható el ugyanez. Azonban „a” értékének van egy alsó határa, amely a konstruált szerkezet méreteiből adódik. A két csapágy közötti távolság, azaz a „b” érték nem növelhető korlátlanul, mert egy bizonyos hosszméret felett a csapágyak tömege nem csökken akkora mértékben, mint amennyivel a tengely tömege növekszik.

A következő táblázatban látható, hogy „a” és „„” értékének változtatásával milyen csapágyazás össztömeg adatokat kapunk eredményül. 
3. táblázat. Csapágy tömegadatok a tengelyméretek függvényében

\begin{tabular}{|c|c|c|c|c|c|c|c|c|c|c|}
\hline $\mathrm{a} \backslash \mathrm{b}$ & 100 & 200 & 300 & 400 & 500 & 600 & 700 & 800 & 900 & 1000 \\
\hline 100 & 1,37 & 0,71 & 0,48 & 0,41 & 0,37 & 0,34 & 0,32 & 0,31 & 0,30 & 0,29 \\
\hline 200 & 2,49 & 1,37 & 0,96 & 0,71 & 0,58 & 0,48 & 0,41 & 0,41 & 0,39 & 0,37 \\
\hline 300 & 4,03 & 1,93 & 1,37 & 1,07 & 0,86 & 0,71 & 0,61 & 0,55 & 0,48 & 0,43 \\
\hline 400 & 6,60 & 2,49 & 1,75 & 1,37 & 1,13 & 0,96 & 0,81 & 0,71 & 0,63 & 0,58 \\
\hline 500 & 10,51 & 3,16 & 2,11 & 1,65 & 1,37 & 1,17 & 1,02 & 0,90 & 0,79 & 0,71 \\
\hline
\end{tabular}

Az alábbi ábrán látható a csapágyak össztömegének tengelyméret függése a 3. táblázat adatai alapján.



4. ábra. Csapágyazás tömegének tengelyméret függése

\subsection{Egysoros mélyhornyú golyóscsapágy költségének meghatározása}

A költségek számításához felvételre kerül néhány csapágy átmérő és a hozzájuk kapcsolódó ár. Az árak nettó árak, Koyo 6200-as csapágy széria. Az árak függenek a valuta árfolyamtól, de ez az optimumkeresést nem befolyásolja jelentősen. Az átmérő - ár függvényt közelítjük lineáris, exponenciális, hatvány és többed fokú polinomok egyenleteivel, majd a legpontosabb közelítést eredményező egyenletet használjuk a számításoknál. Az átmérő - ár függvény első ránézésre exponenciális jelleget mutat, de a vizsgálat és az ellenőrzés során kiderült, hogy másodfokú, harmadfokú és negyedfokú polinommal való közelítés hoz jó értékeket. Korrelációs együttható alapján a negyedfokú polinommal való közelítés a legjobb $(0,98206)$, a második legjobb a harmadfokú polinommal való közelítés $(0,98204)$, harmadik a másodfokú polinommal történő közelítés $(0,98169)$. 
4. táblázat. Csapágy költségek [11]

\begin{tabular}{|c|c|c|}
\hline Típus & $\mathrm{d}[\mathrm{mm}]$ & Ár [Ft] \\
\hline 6002 & 15 & 1092 \\
\hline 6003 & 17 & 1038 \\
\hline 6004 & 20 & 1048 \\
\hline 6005 & 25 & 1120 \\
\hline 6006 & 30 & 1470 \\
\hline 6007 & 35 & 1598 \\
\hline 6008 & 40 & 1896 \\
\hline 6009 & 45 & 3130 \\
\hline 6010 & 50 & 2660 \\
\hline 6011 & 55 & 4048 \\
\hline 6012 & 60 & 4054 \\
\hline 6013 & 65 & 5196 \\
\hline
\end{tabular}

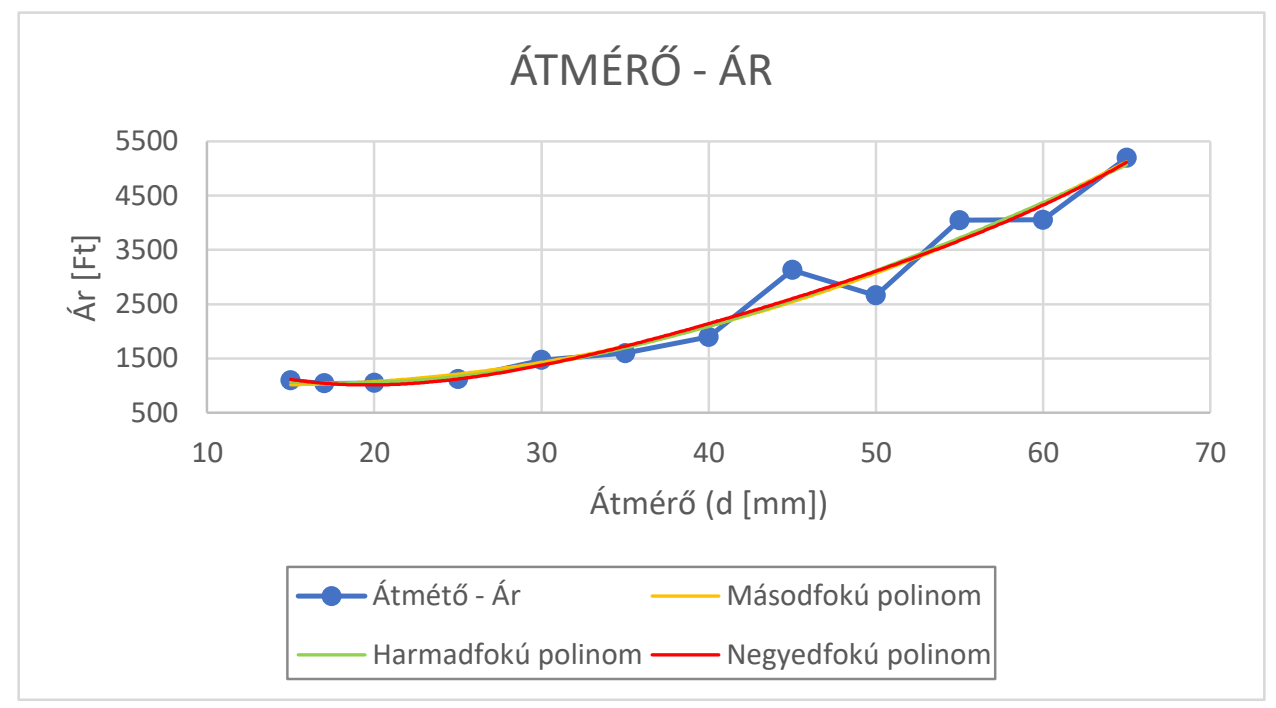

5. ábra. Átmérö - ár függvény

A három görbét leíró függvény egyenletei:

negyedfokú polinom egyenlet:

$$
y=0,0011 \cdot x^{4}-0,1819 \cdot x^{3}+12,563 \cdot x^{2}-315,07 \cdot x+3573,2
$$

harmadfokú polinom egyenlet:

$$
y=-0,0125 \cdot x^{3}+3,0546 \cdot x^{2}-96,534 \cdot x+1866,4
$$


Sztankó, B., Szabó, J. F. Tengelyek csapágyazásának optimálása tömeg-és költségminimumra

másodfokú polinom egyenlet:

$$
y=1,5647 \cdot x^{2}-42,988 \cdot x+1308,5
$$

Az ellenőrzéskor kapott eredményeket mutatja az alábbi táblázat.

5. táblázat. Ellenörzéskor kapott eredmények

\begin{tabular}{|c|c|c|c|c|}
\hline $\mathrm{d}[\mathrm{mm}]$ & Ár [Ft] & $\begin{array}{c}\text { Ár [Ft] } \\
\text { negyedfokú } \\
\text { polinommal } \\
\text { számolva }\end{array}$ & $\begin{array}{c}\text { Ár [Ft] } \\
\text { harmadfokú } \\
\text { polinommal } \\
\text { számolva }\end{array}$ & $\begin{array}{c}\text { Ár [Ft] } \\
\text { másodfokú } \\
\text { polinommal } \\
\text { számolva }\end{array}$ \\
\hline 15 & 1092 & 1115,60 & 1063,49 & 1015,74 \\
\hline 17 & 1038 & 1045,92 & 1046,69 & 1029,90 \\
\hline 20 & 1048 & 1017,80 & 1057,56 & 1074,62 \\
\hline 25 & 1120 & 1135,83 & 1166,86 & 1211,74 \\
\hline 30 & 1470 & 1407,50 & 1382,02 & 1427,09 \\
\hline 35 & 1598 & 1787,15 & 1693,66 & 1720,68 \\
\hline 40 & 1896 & 2245,60 & 2092,40 & 2092,50 \\
\hline 45 & 3130 & 2770,18 & 2568,87 & 2542,56 \\
\hline 50 & 2660 & 3364,70 & 3113,70 & 3070,85 \\
\hline 55 & 4048 & 4049,50 & 3717,51 & 3677,38 \\
\hline 60 & 4054 & 4861,40 & 4370,92 & 4362,14 \\
\hline 65 & 5196 & 5853,73 & 5064,56 & 5125,14 \\
\hline \multicolumn{2}{|r|}{ Átlagos eltérés } & $8,13 \%$ & $0,04 \%$ & $0,001 \%$ \\
\hline
\end{tabular}

Jól látható, hogy a negyedfokú polinommal történt számítás eredményei elég pontosak, de nem biztos, hogy a legjobbak. Tehát jelen adatok felhasználása mellett a harmadfokú vagy a másodfokú polinommal történő közelítés optimumkeresésre sokkal inkább alkalmas.

\subsection{Csapágyazott szerkezet vizsgálata szimulációval}

A rajzok Solid Edge ST10 programmal, a szimulációk ANSYS 13.0 és ANSYS 2019 R2 programmal készültek. A szimulációk készítése során minden alkatrészt elláttam az anyagának megfelelő fizikai tulajdonságokkal. A szimuláció peremfeltételei a számított és a bemenő adatokon alapulnak. Megvizsgáltam a szerkezet deformációja és a létrejövő feszültségek.

A rajz az optimálási folyamat eredményei alapján legalkalmasabbnak talált csapágyak kombinációjával készült. A számítás kiinduló adatai egy mintapéldából származnak. A felhasznált csapágyak típusai: SKF 6207 és SKF 6308.

A végeselemes vizsgálatok az optimálás során optimális végeredményt biztosító csapágytípusra és méretekre vonatkoznak. 

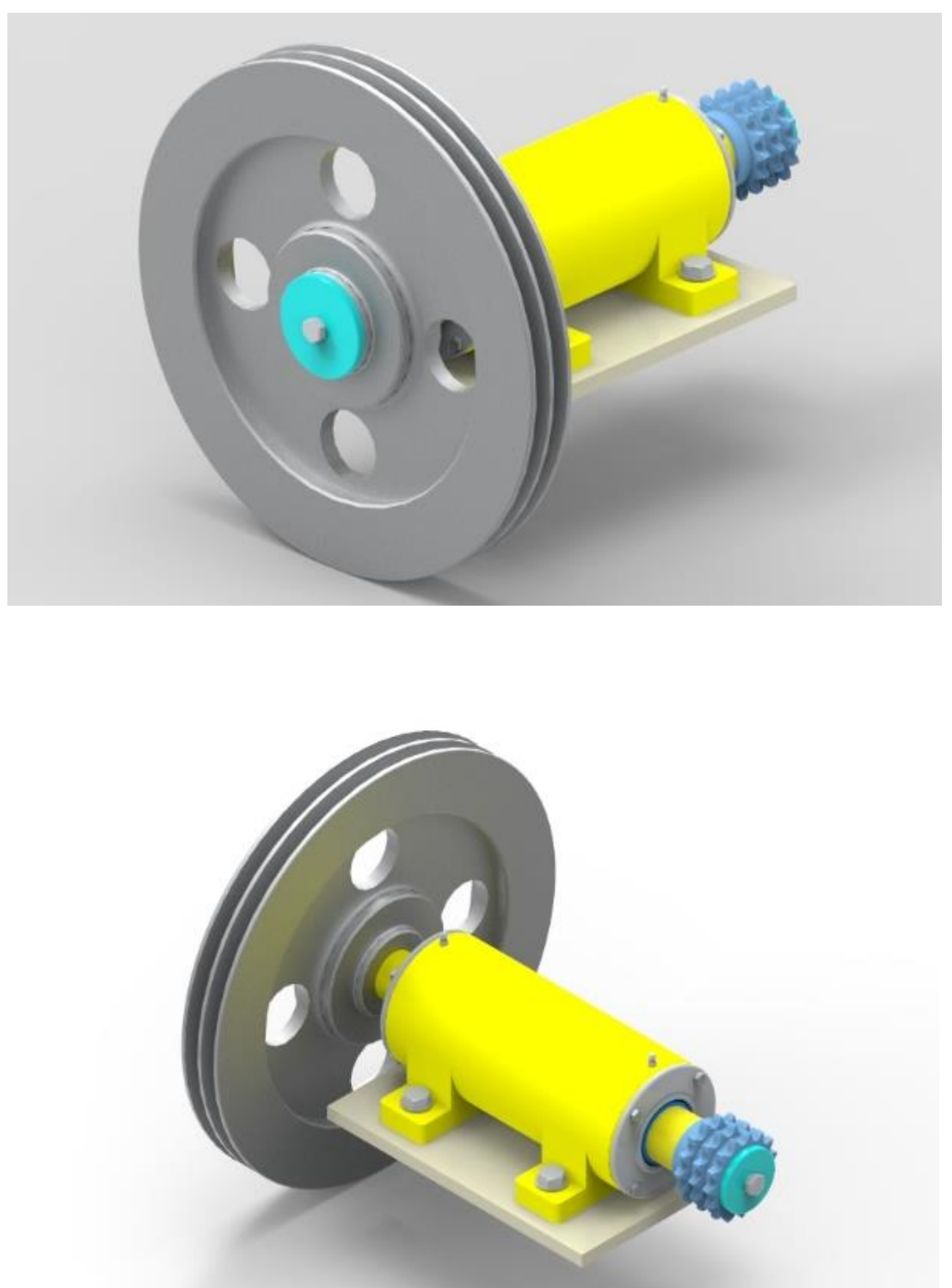

6. ábra. Megvalósitás csőböl készült csapágyházzal 


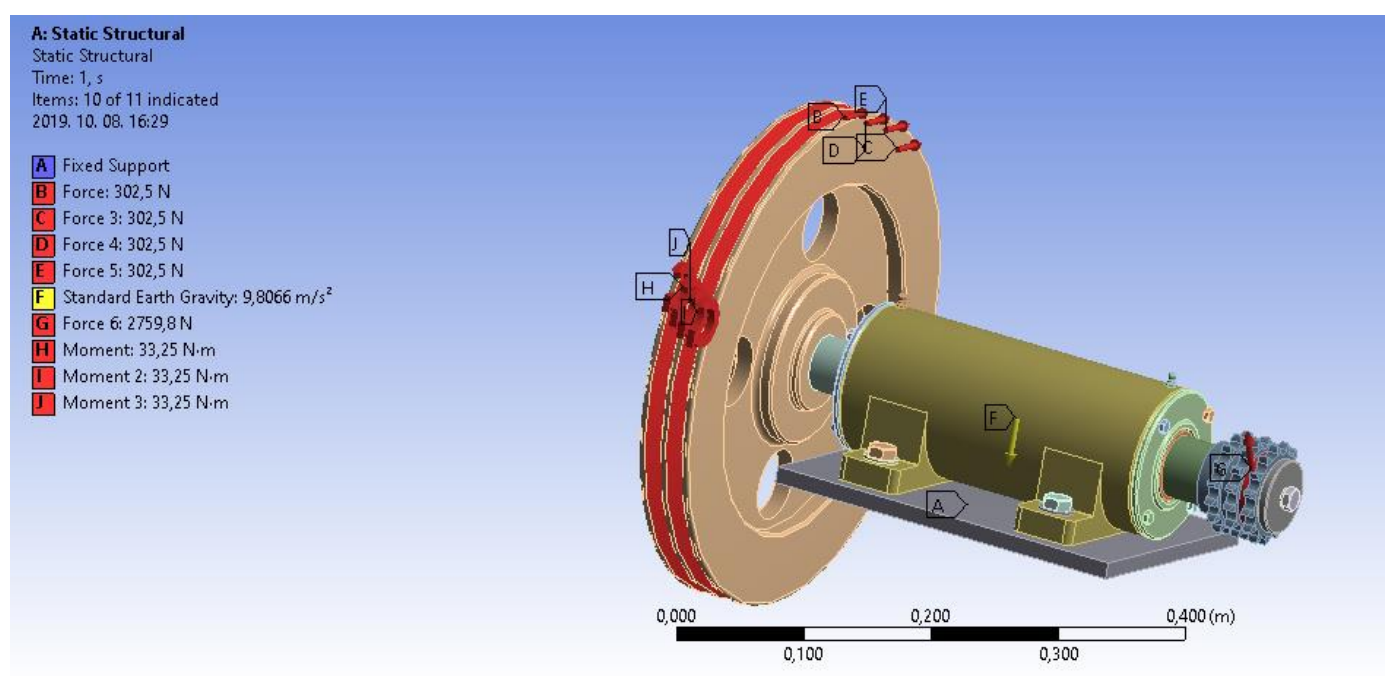

7. ábra. A szimuláció peremfeltételei

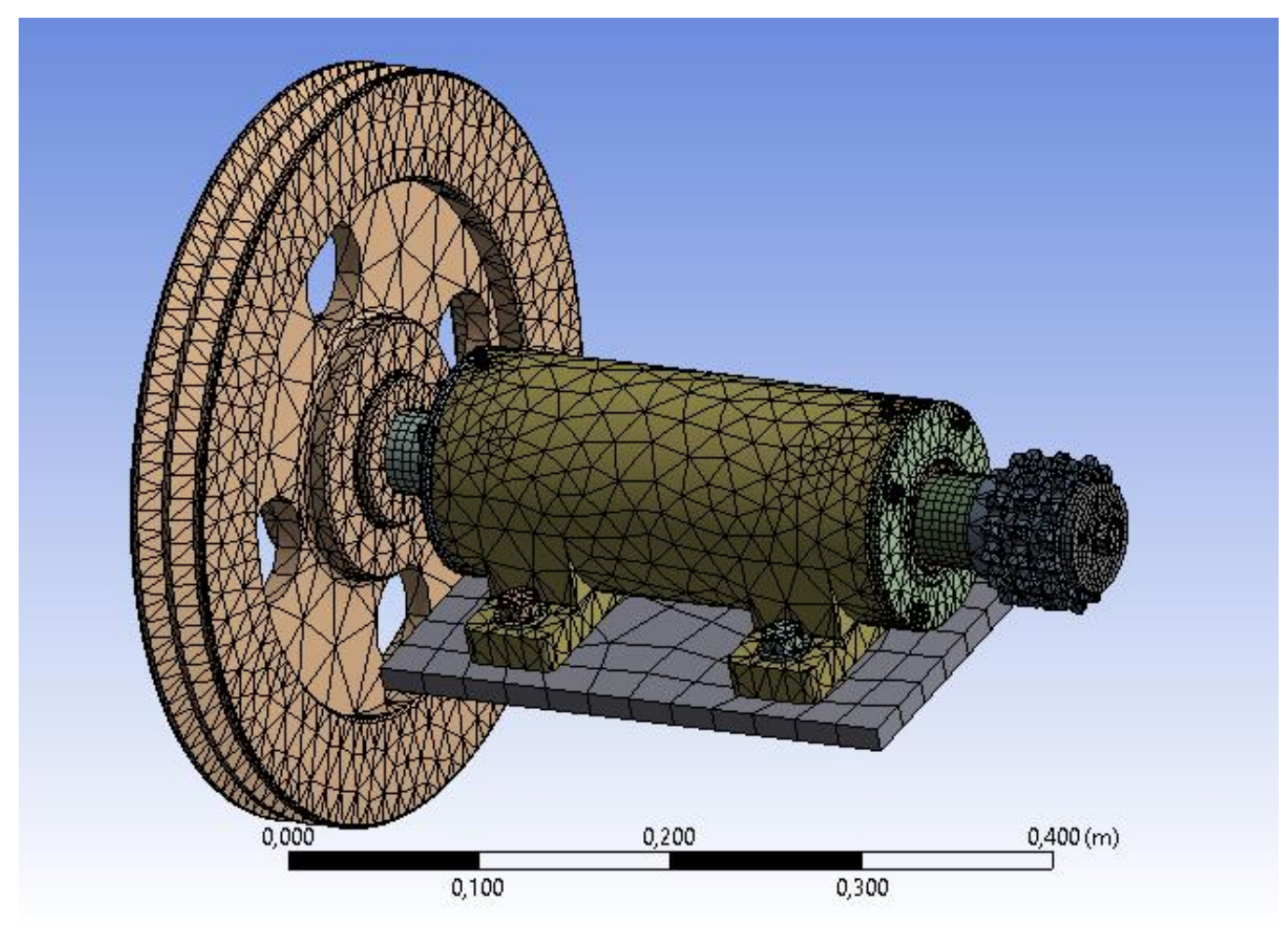

8. ábra. A behálózott modell 

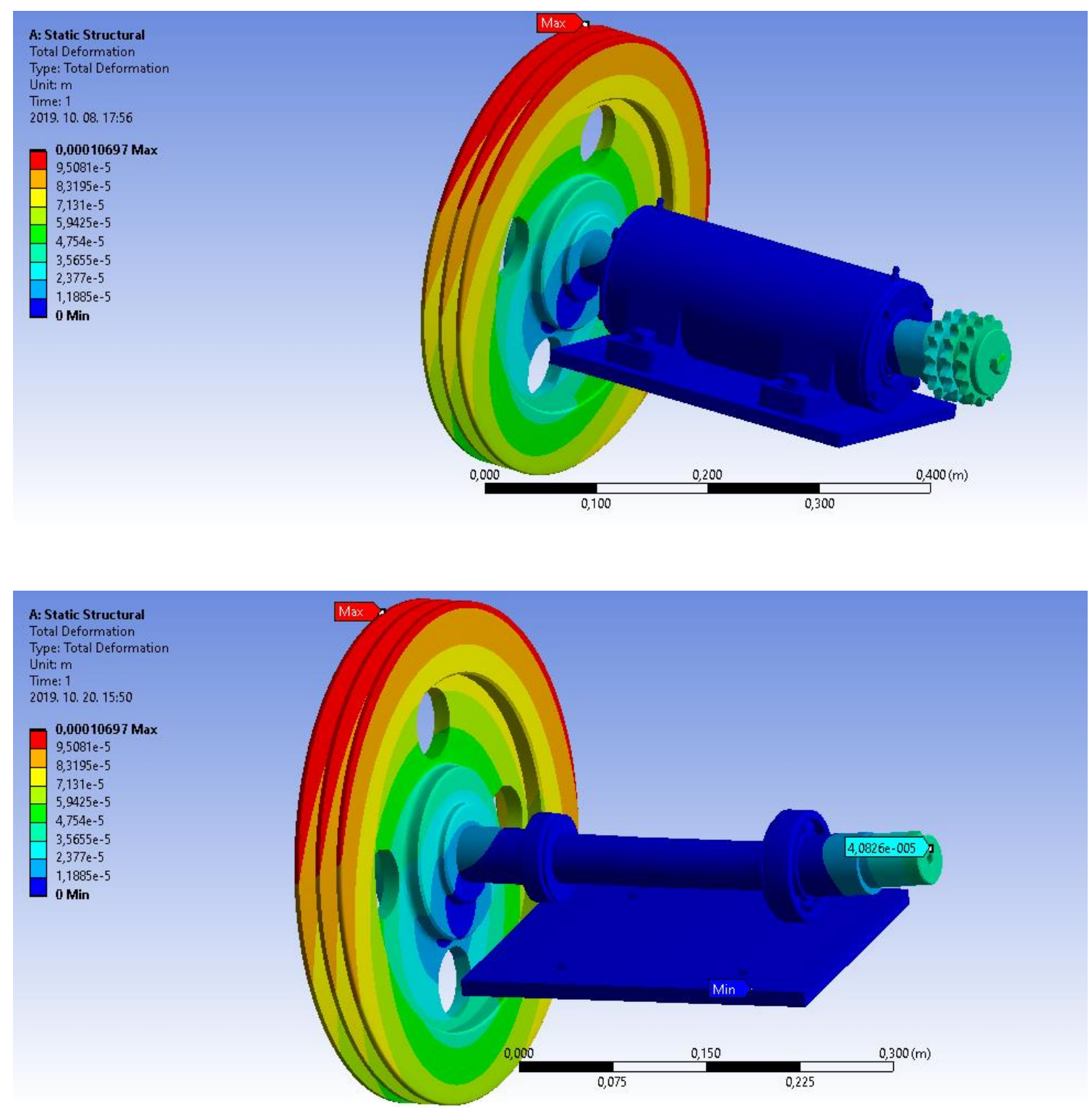

9. ábra. Deformációk a szimulált modellen

A deformációt szemléltető ábrán jól látható, hogy a maximális deformáció a szíjtárcsán található, értéke $1,0697 \cdot 10^{-4} \mathrm{~m}$. Az optimálás számára jelenesetben a tengely deformációja a legfontosabb, legnagyobb értéke $4,0826 \cdot 10^{-5} \mathrm{~m}$.

A fellépő feszültségeket szemléltető ábrán jól látható, hogy a maximális feszültség a szíjtárcsához közelebb lévő csapágynál van, itt a feszültség értéke $1,0536 \cdot 10^{8} P a=105,36 M P a$. Egy $300 \mathrm{MPa}$ folyáshatárú tengely anyag használata esetén 2,5-ös biztonsági tényezőt használva a tengelyben megengedhető feszültség nagysága $120 \mathrm{MPa}$, ami a szimuláció során kapott érték felett van, tehát megfelel. 

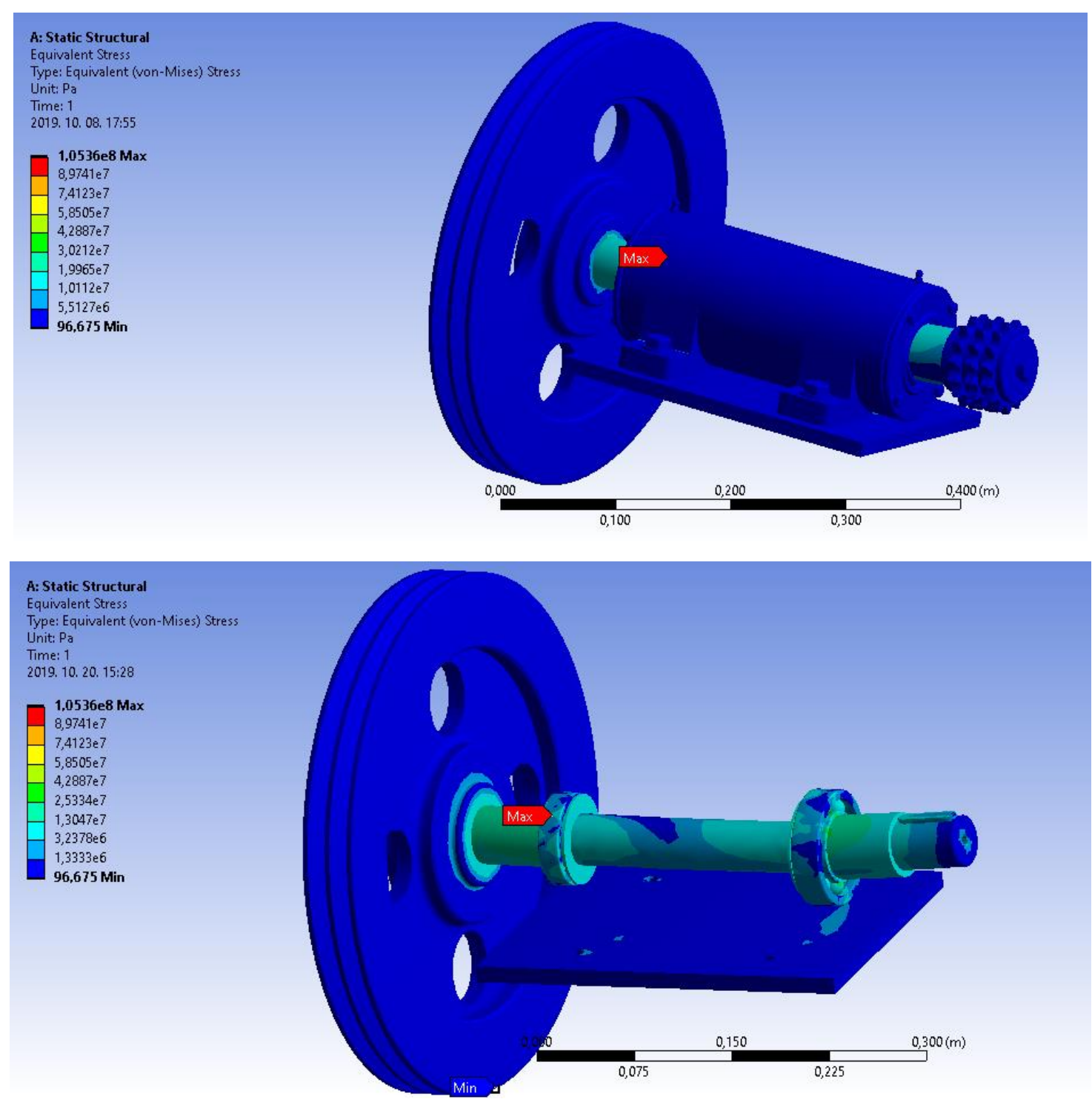

10. ábra. Feszültségek a szimulált modellben

\section{4. Összefoglalás}

Az optimumkereső eljárások segítségével felépíthető egy olyan megoldásmenet, melynek segítségével adott feltételek mellett meghatározható legkisebb csapágytömeg.

A folyamat tovább bővítéseként a csapágyak költéségét is figyelembe kell venni. Ez az új kritérium hatással lehet a már meghatározott optimumra. Végeselemes vizsgálatok segítségével gyors ellenőrzést lehet végezni az optimumkeresés eredményeinek a felhasználásával. Az így kapott eredményekből 
következtetni lehet az optimált szerkezet mechanikai megfelelőségére.

A kapott eredményeket összesítve lehetőség van egy optimális megoldás megvalósításának és annak költésgének meghatározására.

\section{Köszönetnyilvánítás}

A cikkben ismertetett kutató munka az EFOP-3.6.1-16-2016-00011 jelü „Fiatalodó és Megújuló Egyetem - Innovatív Tudásváros - a Miskolci Egyetem intelligens szakosodást szolgáló intézményi fejlesztése" projekt részeként - a Széchenyi 2020 keretében - az Európai Unió támogatásával, az Európai Szociális Alap társfinanszírozásával valósul meg.

\section{Irodalom}

[1] SKF Csapágykatalógus. SKF, 2008. június

[2] Nagy, T.: Feltételes optimalizálás, Egyetemi elektronikus oktatóanyag, Miskolci Egyetem Alkalmazott Matematikai Tanszék, Miskolc, 2012. TÁMOP-4.2.1.B-10/2/KONV-2010-0001

[3] Szabó, F. J., Bihari, Z., Sarka, F.: „Termékek, szerkezetek, gépelemek végeselemes modellezése és optimálása", Szakmérnöki jegyzet HEFOP CAD/CAM/FEM Kompetencia Kurzusok, Miskolci Egyetem, 2006. Gép- és Terméktervezési Intézet: Gépelemek II.; Rugalmas hajtás tervezése segédlet

[4] Szabó, F. J.: Multidisciplinary Optimization of a Structure with Temperature Dependent Material Characteristics, Subjected to Impact Loading, International Review of Mechanical Engineering, 2 (3) pp. 499- 505. (2008)

[5] Szabó, F. J.: Tengelyek csapágyazásának optimálási lehetőségei, The Publications of the MultiScience - XXVIII. microCAD International Multidisciplinary Scientific Conference ISBN: 978-963-358-051-6, Paper No. 26.

[6] Péter, J.: Géptervezés alapjai, Miskolci Egyetemi Kiadó, Miskolc, 2008, ISBN 978-963-661837-7

[7] CNC Media: Hogyan történik a modellek optimalizálása a FEA (végeselem-analízis) használatával? https://www.cnc.hu/2016/08/hogyan-tortenik-a-modellek-optimalizalasa-a-feavegeselem-analizis-hasznalataval/

[8] Szabó, F. J.: Csapágy- költségfüggvények tengelyek csapágyazásának optimálásához, GÉP 64: 7 pp. 42-45., 4 p. (2013)

[9] Erdősné Sélley, Cs., Gyurecz, Gy., Janik J., Körtélyesi, G.: Mérnöki optimalizáció. Typotex Kiadó, 2012. ISBN 978-963-279-538-6

[10] Csapágyak árai: onlinecsapagy.hu 